\title{
DOI: 10.32837/2312-3192/13/6
}

\section{УДК 811.81-139}

\section{THE CONCEPT OF MILKY WAY IN LINGUOSEMIOTIC AND NARRATIVE INTERPRETATION}

\begin{abstract}
Svitlana Volkova*
\section{Abstract}

The paper focuses on linguosemiotic and narrative analysis of MILKY WAY as a multidimensional concept which finds its manifestation in contemporary Amerindian prosaic texts. Thus, the paper integrates linguocultural, ethnocultural, mythological, and linguostylistic aspects of the study the concept. The paper proves the idea that everything in the world is interconnected, and all the processes, which take place in people's life, find their reflection in language forms, which resemble the objects of our reality and embody their meaning in such verbal signs as syntactic structures, their way of arrangement and means of narratability. Based on linguocultural and ethnocultural analysis the paper illustrates with some samples (as vyshyvanka in Ukrainian culture or snake in Amerindian culture) that the Milky Way is not only a sign in the sky, but its philosophy is much deeper as it represents a crossing point, in which differently directed lines like some roads meet, turn direction and continue their movement from one side to the other. It makes a ground for considering it as a road to the Otherworld and a symbol of Unity, Balance and Eternity. The conclusion is made that the perspective of two facets, linguosemiotic and narrative one, makes it possible to reveal and explain the sense of the concept of MILKY WAY manifested in a literary text by different lingual indicators and markers. Liguosemiotic and narrative study the ways of verbalization the concept of MILKY WAY in a literary text, which also involves culturological, ethnocultural, mythological and linguostylistic methods of investigation, allows for the interpretation the Milky Way as a celestial phenomenon, an object that symbolizes the connection of two worlds and the sign of the road to the Otherworld that finds its actualization in verbal and non-verbal narratives.
\end{abstract}

KEYWORDS: concept, Milky Way, sign, symbol, linguosemiotic and narrative perspectives, linguistic markers and indicators, means of actualization.

\section{Introduction}

"There is a high track, seen when the sky is clear, called the Milky Way, and known for its brightness. This way the gods pass to the palaces and halls of the mighty Thunderer (Zeus/Jupiter). Here the powerful and distinguished have made their home. This is the place, if I were to be bold, I would not be afraid to call high heavens Palatine"1.

Milky Way is not only a sign in the sky, it is the concept with its implied meaning, which has philosophical, cultural, ethnocultural, mythological background. Different cultures have their own understanding the concept of Milky Way. What makes the Milky Way so meaningful? The explanation is that the Milky Way, oriented on the north-south direction, forms a cross with the elliptical path of the Sun, symbolizing the linier development transgression and passing to the Otherworld ${ }^{2}$.

It's always interesting to investigate in cognitive focus how it occurs that the object, even having unique form, but representing a single unity, at the same time serves as an icon of two

\footnotetext{
* Svitlana V. Volkova, Prof. Dr., Kyiv National Linguistic University, Velyka Vasilkivska str., 73, 73000, Kyiv, Ukraine, E-mail: volkovasvitlana71@gmail.com.
}

ORCID: 0000-0002-5708-7034

\footnotetext{
${ }^{1}$ Kline 2000

${ }^{2}$ Barnhart 2003
} 
realities (present and past one) combination with strict border of passing from one into another. Which are the semiotic and linguistic markers or indicators of the boundary between that (past) and other (future) worlds messaging by the Milky Way?

Examining the concept in mythological, culturological and cognitive linguistics perspectives, the paper illustrates the co-work of language and mind in actualizing the sense of this concept in literary text. In the novel "Dwellings" by L. Hogan, the work that comprises the linguistic material for the given semiotic and narrative analysis, the message of Milky Way is reinforced through grammar, semantics and syntax.

Concepts are always in the focus of linguistic study. There are highlighted such aspects of the problem as methodology of concepts' reconstruction in linguocognitive and linguoculturological facets 3456 , contrasting and comparing the ethnoconcepts' actualization in different languages 7891011 , concepts in different types of discourses and narratives ${ }^{12} 13141516$, concepts in author's picture of the world ${ }^{17}{ }^{18}$. And it is not the whole list of present-day key interests of the problem.

The scientific search in getting more knowledge about this or that concept sometimes provokes conducting the conferences, where the object of discussing is the concept in intermodal facet $^{19} 2021$. So, for instance, last year's Conference theme of American Semiotic Society "Signs of Resilience in a Complex World" (held in October 2018, KY, USA) was devoted to the sustainability and thrivability of our culture, environment, society, and politics. The concept of RESILIENCE was analyzed much more than a fashionable buzz-word. Following the idea that originally developed as an ecological concept resilience is congruent with the maintenance of semioethnical responsibilities and the preservation of human integrity it was insisted that given our cultural, social, and political climate, we believe the topic of resilience to be timely. One of the main tasks to be discussed at the conference was the resilience of semiotic consciousness and the important contributions of semioticians to the understanding and renewal of the lifeworld. So, nowadays we need to develop semiotic habits that allow us to learn how to navigate through the transmodern world creatively.

The object of the paper is the concept of MILKY WAY, and the subject is in its linguosemiotic means of actualization in narrative structure of present-day Amerindian prosaic texts. The purpose of the study is in highlighting the multidimensional approach of interpretation

\footnotetext{
${ }^{3}$ Dombrovan 2017

${ }^{4}$ Martynyuk 2017

${ }^{5}$ Prihodko

${ }^{6}$ Zhabotinska

${ }^{7}$ Golubovskaya

${ }^{8}$ Kolesnik

${ }^{9}$ Tyshenko

${ }^{10}$ Shutova

${ }^{11}$ Volkova

12 Babelyuk

${ }^{13}$ Demchuk

${ }^{14}$ Marina

15 Potapenko

${ }^{16}$ Volkova

${ }^{17}$ Fedoriva

${ }^{18}$ Vorobyova

${ }^{19}$ Clavere

${ }^{20}$ Palkey

${ }^{21}$ Seif 
the concept of MILKY WAY in present-day Amerindian prosaic texts in linguosemiotic and narrative perspectives. The purpose of the study stipulates the following tasks:

to observe and analyze the way of semiotic understanding the concept of MILKY WAY in different cultures;

to reveal and describe linguosemiotic and narrative means of actualization this concept in present-day Amerindian prosaic texts;

- $\quad$ to highlight the multidimensional approach of interpretation the concept of MILKY WAY in present-day Amerindian prosaic texts in linguosemiotic and narrative perspectives.

\section{Background and motivations}

Semiotic understanding the concept of MILKY WAY in different cultures. Countless studies now exist on the importance of sky watching to Native American life. Like their European counterparts, early men in the New World had many myths about the planets, the stars and the universe. Indigenous built structures from Chile to Alaska have been demonstrated to be observatories and models of the universe in miniature. The application of archaeoastronomy to the studies of New World cultures has greatly aided in the understanding of the customs of those groups. The 1990 National Geographic article entitled "America's Ancient Skywatchers", by John Carlson, is one notable exception ${ }^{22}$.

Barnhart made very good job for those who investigates culturology, semiotics and linguistics in their integrity. For instance, he assumed mythological worldview on the concept of Milky Way by different tribes of the North America.

To the Inca, the Milky Way was, and still is, referred to as a river flowing through the sky. Its source is said to be terrestrial, the run off of the Vilcanota River. The Vilcanota and the Milky Way are said to be mirror images of one another and for this reason the primary orientation of the Milky Way is said to be running southeast/northwest ${ }^{23}$. The Milky Way is also said to be home to a number of animals in the form of what Urton terms "dark star constellations". The dark patches in the Milky Way have names like the Llama, the Toad and the Snake:

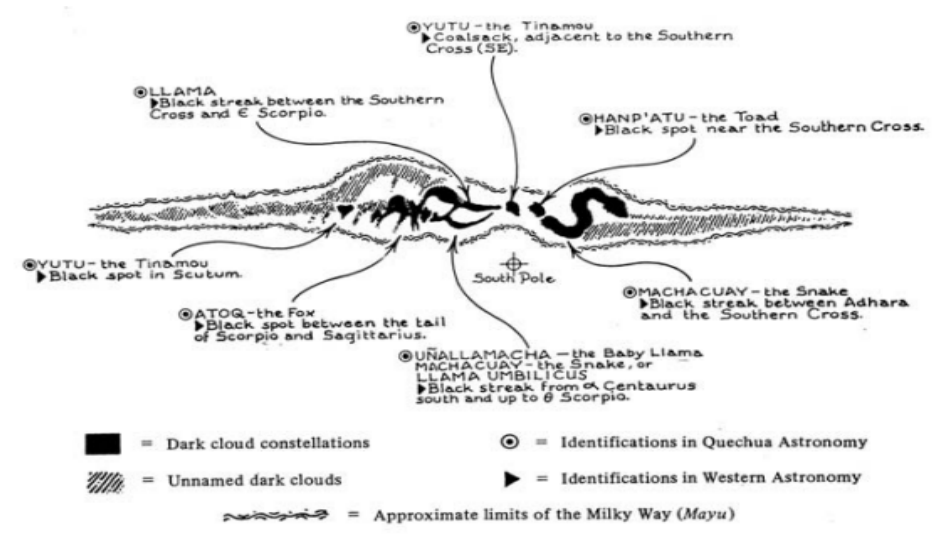

Fig. 1. The Milky Way in Inca's philosophy

For the Maya, both ancient and modern, the Milky Way plays a central role in a reenactment of creation that is cyclically displayed in the night sky. Primarily, it is associated with the World Tree that reaches from Earth into the heavens:

\footnotetext{
${ }^{22}$ Barnhart 2003

${ }^{23}$ Urton 1981

(C) Volkova S., 2019
} 


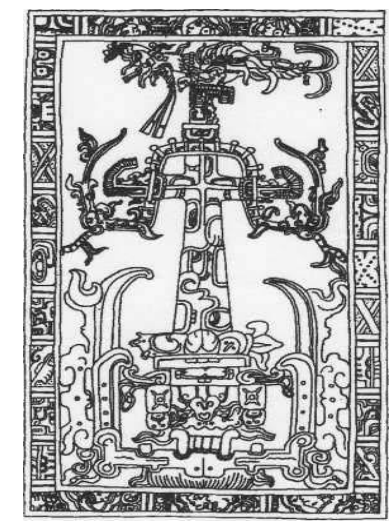

Fig. 2 The Milky Way in the Maya's imagining

The Oglala and Lakota Sioux, according to William K. Powers' book Oglala Religion ${ }^{24}$, believed that souls traveled along the so-called 'Ghost Road' or the Milky Way. They go until they meet an old woman who judges the soul's life on earth and sends it on to the other world or back to earth to be a shade ${ }^{25}$. The light in the Milky Way is the campfires of ghosts on the road ${ }^{26}$.

In some cultures, for instance Ukrainian, the semiotic sense of the Milky Way finds its material application. Treating the Milky Way as a symbol of the road, leading to the future and giving the hope for that future, Ukrainian Vyshyvanka is used as a talisman to protect the person wearing it and to tell a story:
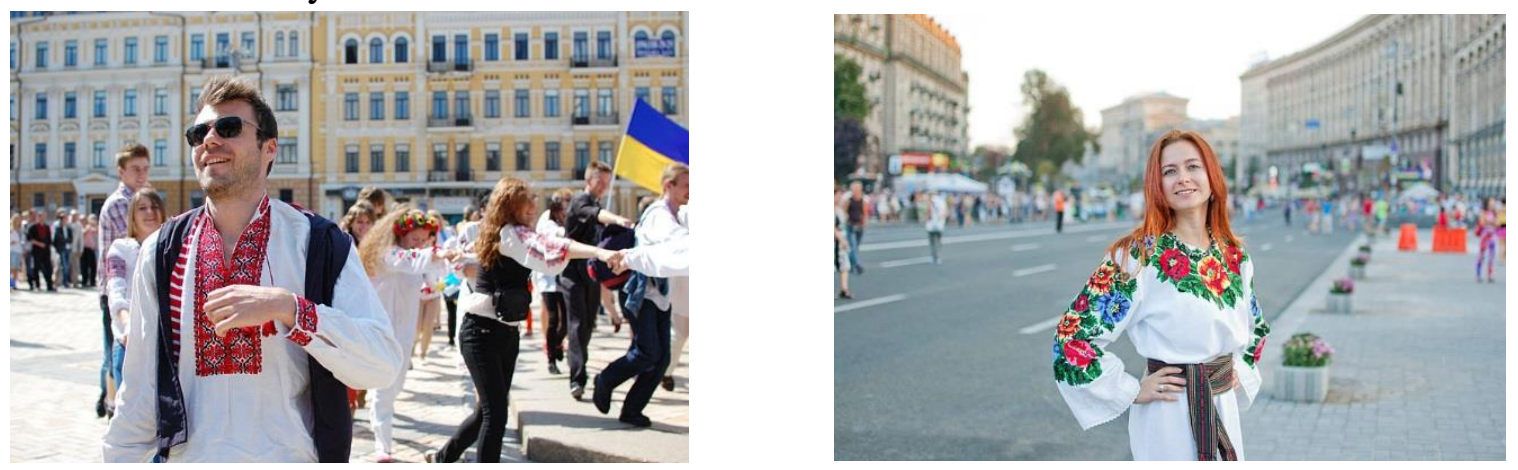

\section{Fig. 3. Samples of Ukrainian vyshyvanka}

Embroidery was used in vulnerable places on the garment where evil spirits could potentially enter the body: along the neckline, cuffs, shoulders, back and hem ${ }^{27}$.

Vyshyvanka Day is celebrated on the third Thursday of May. It is intended to unite all Ukrainians over the world, regardless of religion, language they speak or their place of residence. The word combination "Vyshyvanka Day" means the holiday dedicated to Ukrainian ethnic embroidered cloth and entered to Ukrainian culture as the name of a national holiday of Ukrainian consciousness, patriotism, and the spirit of unity of the people symbolized by Ukrainian vyshyvanka.

The sign of the Milky Way. The notion of concept is treated in the given paper in its semiotic understanding according to $\mathrm{Ch}$. Pierce's semiotic triangle, reflecting the interconnection between sign, meaning and concept. Or in another words, the knowledge about the object of analysis, that in the process of some cognitive operations involved by the interpreter has got its meaning and scientific explanation.

\footnotetext{
${ }^{24}$ Powers 1975

${ }^{25}$ Powers 1975

${ }^{26}$ Powers 1975

${ }^{27}$ Condra 2013

(C) Volkova S., 2019
} 
Thinking over the concept of Milky Way the first thing that comes to our mind is our perception of its image as a sign in the sky. It may be of different design. Let's look at some images of it given below:
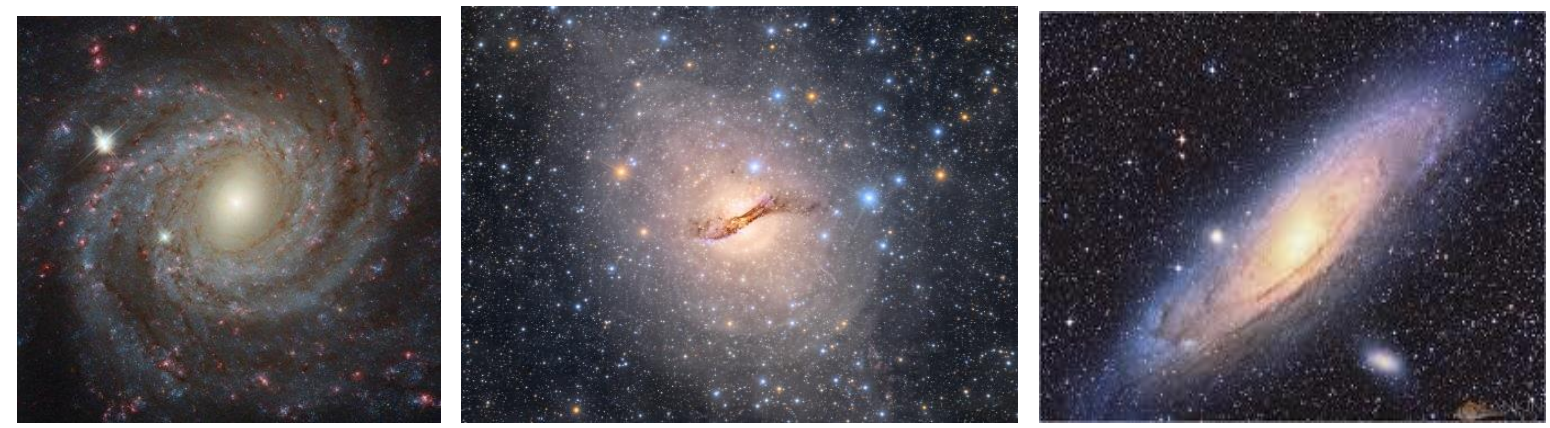

Fig. 4. Verifications in a design of the Milky Way

https://en.wikipedia.org/wiki/Milky_Way\#/media/File:UGC_12158.jpg)

In his book Fire signs. A semiotic theory for graphic design American semiotician Steven Skaggs, thinking on the sense of such notions as semiology and semiotics, writes: "Semiotics refers to the study of signs, their functions and effects. But there are two branches of semiotics [...]. One branch, founded by Swiss linguist Ferdinand de Saussure, conceives the sign as a two-part construction, the union of signifier and a signified. The signifier is the sensed image and the signified is the conception that one has when seeing the sensed image. The other branch derives from the work of American philosopher Charles Sanders Peirce. Instead of Saussure's dyadic (twopart) system, in Peircean semiotics a sign is one member of a three-part relation" ${ }^{28}$. At that, the Saussurian branch is called semiology while the Peircian branch is called semiotics. In our try to analyze the meaning of such visual object as Milky Way it's better to apply to semiotics, but semiology, as semiology has proved difficult to adapt to the non-code aspects of subject matter as visual communication. As Steven Skaggs states, "Peircean semiotics faces no such barriers, it has been slow to be adopted beyond the most superficial level because of its complexity and the abstract terminology Peirce chose to employ".

Turning to Fig.1 and following Skaggs' thoughts, from the standpoint of semiotics both mind and matter are peripheral concepts. Semiotics allows access to that which we call physical and that which we call mental, but in the semiotic world neither concept is central. Instead, the focus is on the actions of signs, and that focus ties together the external and the mental, bypassing the $\mathrm{mind} /$ body dualism of psychology or physiology imagination or design. In my projecting the visual design of Milky Way into its reflection in the text by means of semantics and syntax the definition given by Merriam-Webster's Collegiate Dictionary ${ }^{29}$ will be in a great use. So, this dictionary defines the verb 'design' as "to conceive and plan out in the mind; to have a specific purpose; to devise for a specific function or end". Related to this is the act of expressing the thought about this or that object of reality with an emphasis on the nature of the described thing as some image or creation as well as to make, fashion or construct to express some meaning or pass some message.

"Milky Way" is explained in Macmillan English Dictionary ${ }^{30}$ as the group of planets and stars that the Earth belongs to and that you can see at night as a path of pale light across the sky. It may be treated philosophically as its design regards the circle in the center and some paths curling from different directions to the center:

\footnotetext{
${ }^{28}$ Skaggs 2017

${ }^{29}$ Merriam-Webster's Collegiate Dictionary 2009

${ }^{30}$ Macmillan English Dictionary 2002

(C) Volkova S., 2019
} 


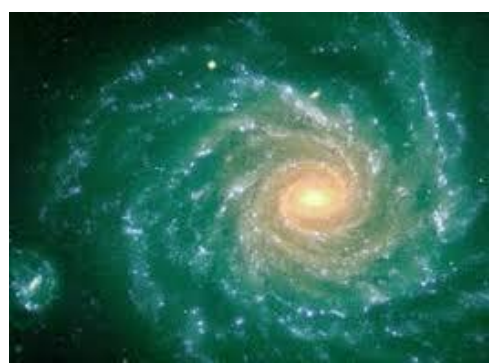

Fig. 5. The image of Milky Way

https://en.wikipedia.org/wiki/Milky_Way\#/media/File:UGC_12158.jpg)

It's a sign that symbolizes the Four Sacred Directions in Medicine of the Cherokee ${ }^{31}$. As J.T. Garrett and Michael Garrett explain: "The Four Directions are the South, West, North, and East. This clockwise circle represents the spiral of life with directional energy that influences our lives. The center of the Four Directions is the Universal Circle, which moves to infinity like rings of water when you toss a rock into a pool. Everything in the Cherokee Way or teachings begins with the fire in the center as the path of the Greater One and the beginning of all living things on Earth. Native Americans respect the council or circle gathering as a "coming together" to hear issues and for resolution, ceremony, and bonding of individual with family, clan, and tribe. The Four Directions represent the Cords of Life, or energies that influence and affect every part of our being $^{\prime 32}$.

That's why Milky Way is treated in Amerindian philosophy of life as a path to the Otherworld $^{33}$.

\section{Methodology}

The paper suggests multidimensional facet of interpretation the ways of actualization of the concept of MILKY WAY in contemporary Amerindian prosaic texts. The integration of methods is in applying of linguosemiotic, narrative, cognitive linguistics, linguocultural and stylistic analyses.

Linguosemiotic approach is based on revealing and realizing the meaning of the Milky Way as a sign that consists of a set of objects, the combination of which resembles a path to the Otherworld. Based on the arguments proved in my previous papers ${ }^{34}$ and the works in semiotics by our contemporary semioticians such as J. Deely, U. Eco, J. Palkey, F. Seif, S. Skaggs, the paper suggests to project the semiotic perception and understanding the image of the Milky Way onto its application in prosaic text at narrative and syntax levels.

Narrative analysis is directed to the finding out the narrative tools of actualization the concept of Milky Way in text narration. Thus, narrative structure, narrative techniques and narration itself, everything that canvases the narratability of the text is in the focus of the given investigation. Narrative analysis is grounded on the theories suggested by W. Schmid ${ }^{35}$, J. Pier ${ }^{36}$, M. Toolan ${ }^{37}$, S. Volkova ${ }^{38}$.

\footnotetext{
${ }^{31}$ J.T. Garrett \& Michael Garrett 1996

32 J.T. Garrett \& Michael Garrett 1996

${ }^{33}$ Barnhart 2003

${ }^{34}$ Volkova 2017; 2018

${ }^{35}$ Schmid 2010

${ }^{36}$ Pier 2014

${ }^{37}$ Toolan 2014

${ }^{38}$ Volkova 2018

(C) Volkova S., 2019
} 
Studying the concept of Milky Way in cognitive linguistic aspect aims at highlighting the cognitive mechanisms of overlapping the mental understanding of concept under investigation in the culture of Amerindians, whose values are highlighted in the prosaic texts taken as factual material in the paper, and the narrative structure itself, and thus explaining the ways of actualization the concept in the prose exploring in the paper.

The knowledge about the concept of Milky Way and its understanding by Amerindians as some symbol and its manifestation in syntactic structure of the texts make us apply the method of syntactic analysis to show the co-work of mentality, semantic and syntax to actualize the concept of Milky Way in the text.

My choice of Amerindian prose as the material of research to illustrate my argument continues my set of works ${ }^{39}$ devoted to this layer of present-day American literature. Pleiades of Native American Renaissance ${ }^{40}$ novelists - Louise Erdrich (Ojibwa), Linda Hogan (Chicksaw), Navarre Scott Momaday (Kiowa), Leslie Marmon Silko (Laguna Pueblo), Gerald Vizenor (Ojibwa), and James Welch (Blackfoot) - promote the idea of ethnocultural values renaissance. They stand for highlighting such concepts as balance, harmony, and cyclicity of life stream ${ }^{41}$.

The present paper focuses on the works by Linda Hogan, a Chickasaw novelist, essayist, and environmentalist. Linda Hogan was born in Denver, Colorado. She earned an undergraduate degree from the University of Colorado-Colorado Springs and an MA in English and creative writing from the University of Colorado-Boulder.

Linda Hogan is the author of the poetry collections, such as Calling Myself Home (1978); Daughters, I Love You (1981); Eclipse (1983); Seeing Through the Sun (1985), which won the American Book Award from the Before Columbus Foundation; Savings (1988), The Book of Medicines, a National Book Critics Circle Award finalist (1993); Rounding the Human Corners (2008); Indios (2012); and Dark. Sweet. New and Selected Poems (2014). Intimately connected to her political and spiritual concerns, Hogan's poetry deals with issues such as the environment and eco-feminism, the relocation of Native Americans, and historical narratives, including oral histories. William Kittredge, in his introduction to Hogan's Rounding the Human Corners, noted, "poets like Linda, through their language, open for us a doorway into their specific resonating dream of the electric universe."

Hogan's collections of prose also reflect her interests in the environment and Native American culture. Her books include the essay collection Dwellings: A Spiritual History of the Living World (1995), The Woman Who Watches Over the World: A Native Memoir (2001), and, with Brenda Peterson, Sighting: The Gray Whales' Mysterious Journey (2002). Together with Brenda Peterson, she edited the anthology The Sweet Breathing of Plants: Women and the Green World (2001) and she is editor of Inner Journey: Views from Native Traditions (2009). A recipient of grants from the National Endowment for the Arts and the Guggenheim Foundation for her fiction, Hogan's novels include Mean Spirit (1990), Solar Storms (1995), Power (1998), and People of the Whale (2008).

Dwellings is about the idea and meaning of home. This book tells us the earth is our universal, spiritual home, through essays about celestial objects, bats, bees, porcupines, wolves, caves and much more.

\footnotetext{
${ }^{39}$ Volkova 2016; 2017

${ }^{40}$ Lincoln 1985

${ }^{41}$ Garrett 1998

(C) Volkova S., 2019
} 


\section{Results and Discussion}

Many of recent theses and papers focusing on the highlighting the aspect of investigating this or that concept in different genres and discourses show that this aspect cannot be fully explored and every scientific discovery opens the next door for one more level of the investigation.

The given paper focuses on the concept of MILKY WAY. Why MILKY WAY? But the factual material is the prosaic text, in which Amerindian culture and such values as harmony, balance, resilience and eternity are highlighted. The answer is that this concept may be treated as having some ethnocultural background and universal at the same time. Thinking over the question of its actualization in a literary text provokes turning to its archetypal side. I mean that the Milky Way is not only a sign in the sky consisted of a set of stars, which look like the road lights and attract our attention by its radiance. Each person feels like traveler, but everybody on the Earth is a temporary citizen, so the archetype of the way that means travelling, changing the state or place, passing from one world into another comprises the preconceptual level of our understanding the concept of the WAY.

Thus, the Milky Way is realized in Amerindian philosophy of life as a path to the Otherworld $^{42}$. To say in more details, its image manifests the unity of two worlds and their transgression from one state into another as it has a strict boundary, which is a marker of such connection: the point, which serves simultaneously the finish of one way and the start of the other. Isn't it the symbol of balance realized through the opposition of death and birth in the nature, continuity (old and new), beauty (set of objects organized in the shape of some roads)? When, for instance, spring finishes and its end gives the birth for the summer and so everything is cycling in the nature. In a such view the Milky Way is unique as it explicates the connection of two different states and their smooth transition from one into another.

In the paper my main task is to show how the concept of MILKY WAY is actualized in semiotic and narrative spaces of Linda Hogan's works.

As it was mentioned above MILKY WAY symbolizes some changes: changing the place, changing the state, changing the direction of a road. It coincides with the idea of Wolf Schmid in his book Narratology. An Introduction (2010), in which Schmid $^{43}$ writes about narrative:

'The change of state that constitutes narrativity implies at least the following:

1) a temporal structure with at least two states, the initial situation and the final situation (the king alive and the king dead);

2) the equivalence of the initial and final situations, that is, the presence of a similarity and a contrast between the states, or, more precisely, the identity and difference of the properties of those states (being alive and being dead form a classical equivalence);

3) both states, and the change that takes place between them, must concern one and the same acting or suffering subject (in our case this is the poor king) ${ }^{44}$.

Linda Hogan's novel Mean spirit is a historical mystery novel grounded on the consequences of species arrogance. Such arrogance is the "mean spirit" that pervaded Oklahoma following the discovery of oil on Indian allotments in the early 1920s. Floods of lawyers, policy makers, and white citizens congregated in Oklahoma in order to legitimize placing Indian women and children in the hands of money-hungry men. During this period, Anglos became legal guardians or custodians of Indian people and lands under the ruse that Indian people were incompetent to

\footnotetext{
${ }^{42}$ Barnhart 2003

${ }^{43}$ Schmid 2010

${ }^{44}$ Schmid 2010

(C) Volkova S., 2019
} 
handle their own affairs. Many characters in Hogan's novel are drawn from actual tribal family histories. Hogan combines history, politics, and mythology in "Mean spirit". In her biographical essay on Hogan, Shanley claims:

As a writer of Chickasaw heritage, Linda Hogan centers herself and, consequently, her readers on what nature has to teach human beings and on the regenerative female forces that shape the world. The Chickasaw were matrilineal and matrilocal in precontact times; other tribes, though patriarchal, revered their women as the creative life force of the universe. Domination by Christian Europeans has altered the traditional tribal balance between male and female power in American Indian life. In her words, Hogan seeks to restore that balance and to offer ancient wisdom about nature in mythological yet contemporary terms ${ }^{45}$.

Now, I turn your attention to the fragment from Hogan's novel "Mean spirit":

All life is sacred. Live gently with the land. We are one with the land. We are part of everything in our world, part of the roundness and cycles of life. The world does not belong to us. We belong to the world. And all life is sacred (L. Hogan "Mean spirit", p. 361-362).

Linguosemiotic interpretation of this excerpt makes us think that we do not inhabit the world, as some have said. Inhabitants invoke the CONTAINER metaphor, which predicates that objects are separate from that which contains them ${ }^{46}$. We belong to a sacred world and are part of everything in it. This precision of meaning is what the author attempts in iconic representation ${ }^{47}$. Hogan does not use 'on' being, but 'of' and 'to' being, that is a part of the world.

The narration is developing like a spiral explicating the changes from a simple sentence to compound unextended and compound extended syntactic structures. The preposition of occurs twice in the middle of the narration. And it is symbolic. The middle of the narration is like the central point of a Milky Way:

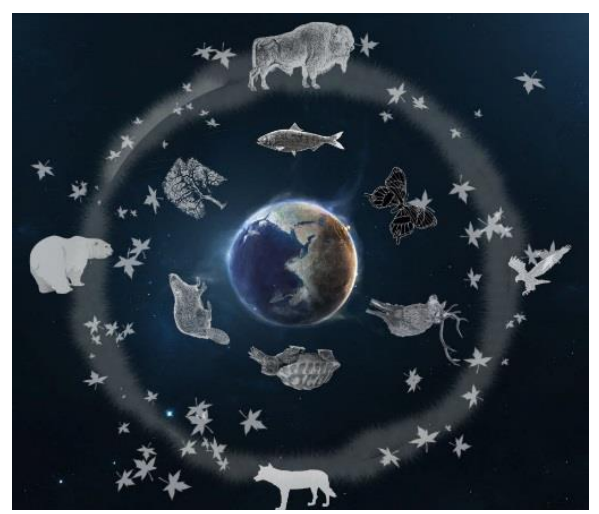

Fig. 6. Cyclicity of life (picture available at: http://www.ancient-pnevma.blogspot.com)

Cycling here is also verbalized by chiasmus 'The world does not belong to us. We belong to the world' Breck ${ }^{48}$ says that "uniqueness of chiasmus, as distinct from other forms of parallelism, lies in its focus upon a pivotal theme, about which the other propositions of the literary unit are developed". In view of this emphasis inherent in chiastic structures, be they literary or oral, Welch suggests that conceptually chiasmus should be conceived of as a series of concentric circles, as opposed to simply a series of parallel lines ${ }^{49}$.

\footnotetext{
${ }^{45}$ Shanley 1997

${ }^{46}$ Freeman 2007

${ }^{47}$ Volkova 2018

${ }^{48}$ Breck 2008

${ }^{49}$ Tollers \& Maier 1990

(C) Volkova S., 2019
} 
In the given above three lines from Mean Spirit by Linda Hogan, syntactic, semantic and narrative structures work together to resemble iconically the cycling of life $\mathrm{e}^{50}$.

In the excerpt from Hogan's Dwellings the narrator thinks over the philosophic understanding of such concepts as LIFE, BEAUTY OF THE WORLD, drawing association between woman and snake:

[...] At first I thought this dream was about Indian tradition, how if each person retained part of a history, an entire culture and lifeway remained intact and alive, one thing living through the other, as the snake and woman in the dream. But since that time, Ive expanded my vision. Now, it seems that what needs to be saved, even in its broken pieces, is earth itself, the tradition of life, the beautiful blue-green world that lives in the coiling snake of the Milky Way (L. Hogan "Dwellings", p. 139).

The object of focalization in this narrative is the Milky Way which is curling like a snake. Thinking over the place of a person in history the author-narrator states, based on her own experience, that entire culture and lifeway remain intact and alive as the snake and the woman in the dream (human perception). And then we can see how speech reflects thinking. Up to the sentence But since that time, I've expanded my vision the narrator uses past tenses, after it we see the shifting of tenses (the narrator becomes using the forms of Present Tense) which symbolizes the road to the Otherworld. And this shifting coincides with semantic of the narrative, as the narrator tells about his expanding in vision.

It looks like the Milky Way, which is a barred spiral galaxy, about 100,000 light-years across. If you could look down on it from the top, you would see a central bulge surrounded by four large spiral arms that wrap around it. Spiral galaxies make up about two-third of the galaxies in the universe (see Fig. 4, Fig. 5).

\section{Conclusions}

It's possible to make some findings from the current research of the concept of Milky Way in linguosemiotic and narrative interpretation that image, language, mind and knowledge are so interwined that the meaning of the object under investigation may be revealed and explained through their cooperation and integration. The paper focuses on the preconceptual level of the concept of MILKY WAY explaining its linguocultural and ethnocultural understanding of its sense. So, this preconceptuality of the MILKY WAY is conceptualized in narrative of literary texts as well as in narrative on clothes print (in case with vyshyvanka). Having analyzed the conceptual and verbal side of the concept the paper draws some inferences that the non-verbal image of the concept manifests the interconnection of two roads with central point, which is the change of the road direction. So, this point symbolizes the unity of two worlds meeting at its center. Projecting this knowledge onto the vyshyvanka's print it may be marked that its print also resembles the Milky Way as stretches from the left sleeve to the right one cycling around the neck which is also considered to be the meeting point of two roads or worlds. At narrative level of a literary text the symbolic meaning of the Milky Way is actualized by means of syntactic structures arrangment with shifting of tenses in one central point manifested semantically and syntactically.

The use of linguosemiotic and narrative approaches to the study of the concept of MILKY WAY in different cultures and literary texts allows for the interpretation of it not only as a celestial phenomenon, but as an object that symbolizes the connection of two worlds and the road to the Otherworld and finds its actualization in verbal and non-verbal narratives.

\footnotetext{
${ }^{50}$ Volkova 2018

(C) Volkova S., 2019
} 


\section{BIBLIOGRAPHY}

Концепты и контрасты : монография / Н. В. Петлюченко, С. И. Потапенко, О. А. Бабелюк, Е. Л. Стрельцов и др. ; под. ред. Н. В. Петлюченко. - Одесса : Издательский дом «Гельветика», 2017. - 632 с.

Barnhart L. Edwin. The Milky Way as the Path to the Otherworld: A Comparison of Pre-Columbian New World Cultures. - Austin: University of Texas Press, 2003. - 16 p.

Breck J. The shape of biblical language: Chiasmus in the scriptures and beyond. - St. Vladimir's Seminary Press, 2008. - 338p.

Condra Jill. Encyclopedia of National Dress: Traditional Clothing Around the World. - ABC-CLIO, 2013. $624 \mathrm{p}$.

Freeman M. H. Poetic iconicity. In Cognition in language / W. Chlopicki, A.Pawelec \& A. Pokojska (eds.). Krakow : Terrium, 2007. - P. 472-501.

Garrett J.T. \& Garrett M. Medicine of the Cherokee. The Way of Right Relationship. - Rochester, Vermont : Bear \& Company Publishing, 1996. -223 p.

Garrett M. Walking on the wind: Cherokee teachings for healing through harmony and balance. - New York : Bear and company publishing, 1998. $-193 \mathrm{p}$.

Hogan L. Dwellings. - New York: Toughstone Book, 1995. - 159 p.

Hogan L. Mean spirit. - NewYork : The Ballantine Publishing Group, 2000. - 377 p.

Kline A. S. Ovid. The Metamorphoses. - Nerthelands : Poetry in Translation, 2000. - 681 p.

Lincoln K. Native American Renaissance. - California : University of California Press, 1985. - 313 p.

Merriam Webster's Collegiate Dictionary. - 11th edition, Kindle Edition, 2009. - 1664 p.

Powers William K. Oglala Religion. - Lincoln/London : University of Nebraska Press, 1975. - 225 p.

Skaggs S. Fire Signs. A Semiotic Theory for Graphic Design. - Cambridge, Massachusetts, London, England: The MIT Press, 2017. -275 p.

Schmid W. Narratology: an Introduction. - Berlin/New York : De Gruter, 2010. - 258 p.

Shanley K. W. Linda Hogan. In Dictionary of literary biography. - Detroit : Bruccoli Clark Layman, 1975. P. 123-130.

Tollers V. L. \& Maier J. Mappings of the biblical terrain: The bible as text. - Lewisburg, PA : Bucknell University Press, 1990.

Urton G. At the Crossroads of the Earth and the Sky - An Andean Cosmology. - Austin: University of Texas Press, 1981. - P. 38.

Volkova S. V. The Semiotics of Folkdance in Amerindian Literary Prose. In Language - Literature - the Arts: A Cognitive-Semiotic Interface. - Frankfurt am Main, · Bern, $\cdot$ New York, $\cdot$ Oxford, $\cdot$ Warszawa, $\cdot$ Wien : Peter Lang Edition, vol. 14. Text - Meaning - Context: Cracow Studies in English Language, Literature and Culture, 2017. - P. 149-164.

Volkova S. V. Iconicity of syntax and narrative in Amerindian prosaic texts. In Lege Artis. Language yesterday, today, tomorrow. - Warsaw : De Gruyter Open, vol. III (1), 2018. - P. 448-479.

\section{REFERENCES}

Barnhart, L. Edwin (2003) The Milky Way as the Path to the Otherworld: A Comparison of Pre-Columbian New World Cultures. Austin: University of Texas Press, 16 p.

Breck, J. (2008). The shape of biblical language: Chiasmus in the scriptures and beyond. St. Vladimir's Seminary Press.

Concepts and contrasts: monography (2017) Petluchenko, N.V., Potapenko, S.I., Babelyuk O.A., Streltsov, E.I. (chief ed. N.V. Petluchenko). Odessa: Publishing House "Helvetika", 632 p.

Condra, Jill (2013). Encyclopedia of National Dress: Traditional Clothing Around the World. ABC-CLIO, p. 624.

Freeman, M.H. (2007). Poetic iconicity. In Cognition in language. Chlopicki, W., Pawelec, A., \& Pokojska, A. (eds.). Krakow: Terrium, pp. 472-501.

Garrett, J.T. \& Garrett, M. (1996) Medicine of the Cherokee. The Way of Right Relationship. Rochester, Vermont: Bear \& Company Publishing, 223 p.

Garrett, M. (1998). Walking on the wind: Cherokee teachings for healing through harmony and balance. New York: Bear and company publishing, $193 \mathrm{p}$.

Hogan, L. (1995). Dwellings. New York: Toughstone Book, 159 p. 
Hogan, L. (2000). Mean spirit. NewYork: The Ballantine Publishing Group, 377 p.

Kline, A.S. (2000) Ovid. The Metamorphoses. Nerthelands: Poetry in Translation, 681 p.

Lincoln, K. (1985). Native American Renaissance. California: University of California Press, 313 p.

Merriam Webster's Collegiate Dictionary (2009). 11th edition, Kindle Edition, 1664 p.

Powers, William K. (1975) Oglala Religion. Lincoln/London: University of Nebraska Press, 225 p.

Skagga. S. (2017) Fire Signs. A Semiotic Theory for Graphic Design. Cambridge, Massachusetts, London, England: The MIT Press, 275 p.

Schmid, W. (2010) Narratology: an Introduction. Berlin/New York : De Gruyter, 258 p.

Shanley, K.W. (1997). Linda Hogan. In Dictionary of literary biography. Detroit: Bruccoli Clark Layman, 175, p. $123-130$.

Tollers, V. L. \& Maier J. (1990). Mappings of the biblical terrain: The bible as text. Lewisburg, PA: Bucknell University Press.

Urton, Gary (1981) At the Crossroads of the Earth and the Sky - An Andean Cosmology. Austin: University of Texas Press, p. 38.

Volkova, S.V. (2017) The Semiotics of Folkdance in Amerindian Literary Prose. In Language - Literature the Arts: A Cognitive-Semiotic Interface. Frankfurt am Main $\cdot$ Bern $\cdot$ New York $\cdot$ Oxford $\cdot$ Warszawa $\cdot$ Wien: Peter Lang Edition, vol. 14. Text - Meaning - Context: Cracow Studies in English Language, Literature and Culture, pp. 149 -164 .

Volkova, S.V. (2018) Iconicity of syntax and narrative in Amerindian prosaic texts. In Lege Artis. Language yesterday, today, tomorrow. Warsaw: De Gruyter Open, vol. III (1), pp. 448-479.

\begin{abstract}
Анотація.
Статтю присвячено семіотично-наративному аналізу способів актуалізації концепту ЧУМАЦЬКИЙ ШЛЯХ у художньому тексті. Вирішення поставленого завдання у лінгвосеміотичному й наративному ключі одночасно передбачало інтеграцію методів лінгвокультурологічного, етнокультурного, міфологічного й лінгвостилістичного аналізу. У роботі доведено, що все у світі взаємопов'язанеб всі професи, що відбуваються у природі тим чи іншим способом відтворюються у мові та мисленні. У статті провокується ідея іконічного відтворення форми об'єктів реальності, а також їхнього сенсу, мовою тексту засобом аранжування синтаксичних конструкцій на лексичному рівні і наративними способами (циклічність, повтори) на наративному. Грунтуючись на культурологічних i етнокультурних знаннях про чумацький шлях і прикладами його маніфестації в різних етнокультурах (до прикладу, вишиванка в українській культурі, або змія як символ Творця в амеріндіанській), у статті стверджується, що Чумацький Шлях $є$ не просто знак у небі, що його філософія $є$ глибшою, а символіка - ширшою, оскільки він символізує поєднання доріг, які мають точку перетину. Отже, Чумацький Шлях - це шлях до іншого (нового) світу, а його знаковість полягає в тому, що він $\epsilon$ символом Поєднання, Балансу і Щастя. Зроблено висновок, що розгляд зазначеної проблеми у фокусі лінгвосеміотичної й наративної перспектив уможливлює аналіз будь-якого концепту, актуалізованого в художньому тексті мовними індикаторами. Застосування семіотично-наративного підходу до вивчення феномену концепту ЧУМАЦЬКИЙ ШЛЯХ уможливив його аналіз не тільки, як космічне тіло, а й об'єкт, що символізує зв'язок двох світів і дорогу в Новий світ, що знаходить своє вербальне й невербальне втілення в різних наративах..
\end{abstract}

Ключові слова: концепт, Чумацький Шлях, знак, символ, семіотична й наративна перспектива, лінгвістичні маркери та індикатори, засоби актуалізації.

Received 17 April 2019

Reviewed 17 May 2019

Similarity index by Unicheck ${ }^{T M}: 15.8 \%$ 